See discussions, stats, and author profiles for this publication at: https://www.researchgate.net/publication/319051564

\title{
Energy and protein requirements for maintenance of dairy goats during pregnancy and their efficiencies of use
}

Article in Journal of Animal Science · September 2017

DOI: $10.2527 /$ jas.2017.1490

CITATIONS

0

7 authors, including:

Carla Joice Härter

Universidade Federal de Pelotas

48 PUBLICATIONS 186 CITATIONS

SEE PROFILE

Astrid Rivera

National University of Colombia

19 PUBLICATIONS 87 CITATIONS

SEE PROFILE

Some of the authors of this publication are also working on these related projects:

Project Prediction of the chemical composition of the forage Cenchrus clandestinus using Near Infrared Spectroscopy - NIRS View project

Growig goats metabolism View project

READS

330

Douglas Castagnino

Nutreco Canada Inc., Saint-Hyacinthe, Canada

28 PUBLICATIONS 168 CITATIONS

SEE PROFILE

I. A. M. A. Teixeira

UNESP São Paulo State University

118 PUBLICATIONS 635 CITATIONS

SEE PROFILE 


\title{
Energy and protein requirements for maintenance of dairy goats during pregnancy and their efficiencies of use ${ }^{1}$
}

\author{
C. J. Härter, ${ }^{2}$ L. D. Lima, H. G. O. Silva, D. S. Castagnino, \\ A. R. Rivera, K. T. Resende, and I. A. M. A. Teixeira \\ São Paulo State University (UNESP), School of Agricultural and \\ Veterinarian Sciences, Jaboticabal, SP, Brazil 14884-900
}

\begin{abstract}
It has been suggested that maintenance requirements are similar among animals of different physiological stages; however, important physiological changes occur in the maternal body during pregnancy. Therefore, the aim of this study was to determine the energy and protein requirements for the maintenance of pregnant dairy goats and to estimate their efficiency of energy and protein utilization for maintenance and pregnancy. We used 66 multiparous pregnant goats having $49.0 \pm 1.59 \mathrm{~kg}$ initial BW (around the third or fourth parturition) arranged in a randomized block design with a $3 \times 3$ factorial scheme including slaughter at different days of pregnancy (DOP; 80, 110, and $140 \mathrm{~d}$ ) and feed restriction $(0,20$, and $40 \%$ feed restriction). The comparative slaughter technique was used to estimate energy and protein maintenance requirements. Goats slaughtered at $140 \mathrm{DOP}$ were subjected to digestibility trials at around 80,110, and 140 DOP to estimate diet metabolizability and $\mathrm{N}$ balance (NBAL). Metabolizability decreased with feed restriction and was $63.3 \pm 2.16$, $55.7 \pm 2.35$, and $58.2 \pm 2.30 \%$ at 0,20 , and $40 \%$ of feed restriction, respectively $(P<0.01)$. There was no effect of DOP on $\mathrm{NE}_{\mathrm{m}}$ or the requirements of $\mathrm{ME}$ for
\end{abstract}

maintenance $\left(\mathrm{ME}_{\mathrm{m}}\right)$, which were 197 and $315 \mathrm{~kJ} / \mathrm{kg}$ empty body weight $(\mathrm{EBW})^{0.75}$, respectively, and the efficiency of ME utilization for maintenance $\left(\mathrm{k}_{\mathrm{mE}}\right)$ was 0.63 . Similarly, DOP did not affect thedaily net protein requirements for maintenance $\left(\mathrm{NP}_{\mathrm{m}}\right)$ estimated using the comparative slaughter technique $(1.38 \pm$ $\left.0.512 \mathrm{~g} / \mathrm{kg} \mathrm{EBW}^{0.75} ; P=0.003\right)$ or the $\mathrm{NP}_{\mathrm{m}}$ estimated using NBAL $\left(2.49 \pm 0.594 \mathrm{~g} / \mathrm{kg} \mathrm{EBW}^{0.75} ; P<\right.$ 0.01). The MP requirement for maintenance $\left(\mathrm{MP}_{\mathrm{m}}\right)$ estimated using the comparative slaughter technique was not affected by DOP and was $3.22 \mathrm{~g} \mathrm{MP} / \mathrm{kg}$ $\mathrm{EBW}^{0.75}(P<0.01)$. The efficiency of MP utilization for maintenance $\left(\mathrm{k}_{\mathrm{mP}}\right)$ was 0.43 . The efficiency of $\mathrm{ME}$ utilization for pregnancy $\left(\mathrm{k}_{\mathrm{pE}}\right)$ increased with the progress of pregnancy and was $0.058,0.10$, and 0.19 at 80,110 , and 140 DOP, respectively. Similarly, the efficiency of MP utilization for pregnancy $\left(\mathrm{k}_{\mathrm{pP}}\right)$ increased with DOP and was $0.12,0.21$, and 0.43 at 80,110 , and 140 DOP, respectively. There was no evidence that pregnancy affected $\mathrm{NE}_{\mathrm{m}}, \mathrm{ME}_{\mathrm{m}}, \mathrm{NP}_{\mathrm{m}}$, and $\mathrm{MP}_{\mathrm{m}}$ or $\mathrm{k}_{\mathrm{mE}}$ and $\mathrm{k}_{\mathrm{mP}}$, which were also unaffected by DOP. However, $\mathrm{k}_{\mathrm{pE}}$ and $\mathrm{k}_{\mathrm{pP}}$ increased with pregnancy progress as a response to the physiological changes that pregnant females are subjected to.

Key words: efficiency, metabolizable energy, metabolizable protein, nutritional demands

(C) 2017 American Society of Animal Science. All rights reserved.

J. Anim. Sci. 2017.95:4181-4193 doi:10.2527/jas2017.1490

\section{INTRODUCTION}

\footnotetext{
${ }^{1}$ We thank the São Paulo Research Foundation (FAPESP) for providing financial support (grants numbers 2013/04758-5, 2009/10125-0, and 2007/58239-8). No conflict of interest was declared.

${ }^{2}$ Corresponding author: harter.carla@gmail.com

Received February 20, 2017.

Accepted July 2, 2017.
}

During pregnancy of ruminants, physiological adjustments occur in the maternal body to ensure fetal and mammary gland development (Bell and Ehrhardt, 2000; Castagnino et al., 2015). It is known that pregnancy induces adaptive responses in maternal hepatic synthesis and peripheral tissue utilization of glucose (Bell and Bauman, 1997); pregnant females increase 
basal metabolism because of the increase of blood volume, renal and respiratory work, adaptations in the cardiovascular system, greater tissue synthesis, and increase of fetal placental blood flow (U.S. Institute of Medicine, 1990; Mattison et al., 1991; Reynolds et al., 2006). Therefore, due to such physiological adjustments, our hypothesis is that energy and protein requirements for maintenance of goats may change during pregnancy.

At the beginning of pregnancy there are substantial hormonal changes to prepare the maternal body for pregnancy (Hafez and Hafez, 2000), which does not imply changes in body composition. The major changes in maternal body composition and DMI of goats have been observed only after $80 \mathrm{~d}$ of pregnancy (i.e., midterm pregnancy), specially with goats carrying twins (Castagnino et al., 2015). The decrease of DMI observed in the last third of pregnancy occurs simultaneously with the increase of energy and protein requirements (Härter et al., 2016). Furthermore, control of metabolism during pregnancy involves homeostasis and homeorhesis regulation (Bauman and Currie, 1980). Therefore, it is suggested that such physiological changes during pregnancy may increase the efficiencies of energy and protein use for maintenance as well as for pregnancy.

In the current feeding systems used worldwide for goats, energy and protein maintenance requirements are based on data obtained from adult and nonpregnant goats as well as from sheep data (AFRC, 1998; NRC, 2007). In addition, there is scarce information in the literature about the efficiency of ME and MP utilization in pregnant goats. Therefore, the objective of this study was to determine the energy and protein maintenance requirements of goats and to estimate the efficiencies of energy and protein utilization during pregnancy.

\section{MATERIALS AND METHODS}

The experiment was performed to determine the energy and protein requirements for maintenance of dairy goats (Saanen and Oberhasli breeds) during pregnancy. The comparative slaughter technique was used to estimate maintenance requirements. Humane animal care and handling procedures were performed according to guidelines set by the Committee on Ethical Animal Welfare (CBEA; São Paulo State University [UNESP]), School of Agricultural and Veterinarian Sciences (Jaboticabal, Brazil). The project was approved by CBEA under protocol number 026167-07.

Goats were mated either during natural estrus or after induced estrus (during the seasonal anestrus) using a hormone regimen recommended by Ritar et al. (1984) and Freitas et al. (1996). Once estrus was confirmed, females were individually exposed to a male for natural mating. Two males were used in this ex- periment, 1 of each breed (i.e., Saanen and Oberhasli). Within breed, all females were mated to the same male. After mating, the goats were placed in individual stalls equipped with a feeder and automatic water supplier.

Between 35 and $45 \mathrm{~d}$ of pregnancy (DOP), ultrasonographies were performed to confirm pregnancy and determine litter size. As single pregnancies are less common in goats and a previous study showed that maternal body (MB; considered the pregnant goat body disregarding the gravid uterus and mammary gland) metabolism does not change with litter size (Castagnino et al., 2015), only does carrying twins were included in this study.

The study used a total of 66 multiparous (around the third or fourth parturition) pregnant goats weighing 49.0 $\pm 1.57 \mathrm{~kg} \mathrm{BW}$ (at mating) carrying twins. Eight pregnant goats (baseline animals) fed ad libitum were slaughtered at 50 DOP (baseline slaughter date) to estimate initial body composition and to calculate energy and protein retention from 50 DOP to 80,110 , or 140 DOP. The remained 58 pregnant dairy goats weighing $49.8 \pm 1.57 \mathrm{~kg}$ $\mathrm{BW}$ at mating were randomly distributed into 3 groups according to gestational length (80, 110, and 140 DOP). Each group was divided into blocks containing 3 pregnant does with similar breed and BW at mating, and each doe within a block was randomly subjected to a different feed restriction $(0,20$, or $40 \%)$. Then, the experiment was performed in a randomized incomplete block design with a $3 \times 3$ factorial treatment structure, including DOP (80, 110, and $140 \mathrm{~d})$ and feed restriction $(0,20$, and $40 \%$ feed restriction; Supplementary Fig. S1 [see the online version of the article at http://journalofanimalscience.org]). In short, the experiment was composed of 8 blocks within 80 DOP (6 complete blocks and 2 incomplete blocks), 7 blocks within 110 DOP (6 complete blocks and 1 incomplete block), and 7 blocks within 140 DOP (6 complete blocks and 1 incomplete blocks; Supplementary Fig. S1 [see the online version of the article at http://journalofanimalscience.org]).

Pregnant does started being subjected to feed restriction at, on average, $36.8 \pm 0.998$ DOP (i.e., after ultrasonographies) and continued until the target slaughter DOP was reached. Animals without feed restriction $(0 \%)$ were fed ad libitum, with the daily feed amount offered adjusted to allow $15 \%$ orts. The amount of feed offered daily to animals subjected to 20 and $40 \%$ feed restriction was based on the amount of feed consumed on the previous day by goats fed ad libitum within the block. Orts from goats fed ad libitum were collected daily, and composite samples were taken every $30 \mathrm{~d}$. The diet (Table 1) was formulated to meet the nutritional requirements of pregnant goats as defined by the NRC (2007). Animals were fed twice daily, at 0730 and $1700 \mathrm{~h}$. Maintenance requirements were estimated using the comparative slaughter 
Table 1. Chemical composition of the ingredients in the experimental diet, expressed on a DM basis

\begin{tabular}{|c|c|c|c|c|c|c|c|c|c|c|c|}
\hline Ingredient & $\begin{array}{c}\text { Ingredient, \% of } \\
\text { diet, DM basis }\end{array}$ & $\begin{array}{c}\mathrm{DM}, \\
\%\end{array}$ & $\begin{array}{c}\mathrm{GE}, \mathrm{MJ} / \mathrm{kg} \\
\text { of DM }\end{array}$ & $\begin{array}{l}\text { CP, \% } \\
\text { of DM }\end{array}$ & $\begin{array}{c}\text { SolP, } \\
\% \text { of } \mathrm{CP}^{3}\end{array}$ & $\begin{array}{c}\text { SolNP, } \\
\% \text { of } \mathrm{CP}^{3}\end{array}$ & $\begin{array}{c}\mathrm{SDP}^{3} \\
\% \text { of } \mathrm{CP}^{4}\end{array}$ & $\begin{array}{c}\mathrm{ADIP}^{4} \\
\% \text { of } \mathrm{CP}^{5}\end{array}$ & $\begin{array}{l}\mathrm{EE}, 5 \% \\
\text { of DM }\end{array}$ & $\begin{array}{l}\text { NDF, } \% \\
\text { of DM }\end{array}$ & $\begin{array}{r}\text { Ash, \% } \\
\text { of DM }\end{array}$ \\
\hline Cracked corn & 32.9 & 82 & 16.3 & 10.2 & 24 & 17.5 & 73 & 3.2 & 2.9 & 16.9 & 1.97 \\
\hline Soybean meal & 12.3 & 83.1 & 17.4 & 51.8 & 30.4 & 16 & 67.2 & 23.7 & 1.86 & 22.2 & 6.31 \\
\hline Dehydrated corn plant & 44 & 85.2 & 16.1 & 10.22 & 9.5 & 9.03 & 50.6 & 39.9 & 1.71 & 58 & 4.24 \\
\hline Tifton 65 hay & 10 & 87.2 & 16.1 & 7.76 & 29.3 & 4.5 & 50.2 & 16 & 0.94 & 78.4 & 6.6 \\
\hline Mineral premix ${ }^{6}$ & 0.38 & 99 & - & - & - & - & - & - & - & - & 99.9 \\
\hline $\mathrm{NaCl}$ & 0.07 & 98 & - & - & - & - & - & - & - & - & 99.1 \\
\hline Limestone & 0.33 & 95 & - & - & - & - & - & - & - & - & 99.1 \\
\hline Diet composition & & 84.2 & 16.2 & 15.0 & 18.7 & 12.1 & 59.6 & 23.1 & 2.03 & 41.7 & 4.73 \\
\hline
\end{tabular}

${ }^{1} \mathrm{SolP}=$ soluble protein; SolP is nonprotein $\mathrm{N}$ assumed to be instantly degraded in the rumen and the true protein that rapidly escapes from in situ bags.

${ }^{2}$ SolNP $=$ nonprotein $\mathrm{N}$.

${ }^{3} \mathrm{SDP}=$ insoluble protein (that is potentially degradable); this is the $\mathrm{B}$ fraction.

${ }^{4} \mathrm{ADIP}=$ acid detergent insoluble protein.

${ }^{5} \mathrm{EE}=$ ether extract.

${ }^{6}$ Premix contained (per kg) $190 \mathrm{~g} \mathrm{Ca}, 90 \mathrm{~g} \mathrm{Cl}, 73 \mathrm{~g} \mathrm{P}, 62 \mathrm{~g} \mathrm{Na}, 44 \mathrm{~g} \mathrm{Mg}, 30 \mathrm{~g} \mathrm{~S}, 940 \mathrm{mg} \mathrm{Mn}$, a maximum of $730 \mathrm{mg} \mathrm{F}, 340 \mathrm{mg} \mathrm{Cu}, 16 \mathrm{mg} \mathrm{I}, 10 \mathrm{mg} \mathrm{Se}$, $3 \mathrm{mg} \mathrm{Co}, 1.35 \mathrm{mg} \mathrm{Zn}$, and $1.06 \mathrm{mg}$ Fe.

technique according to the method proposed by Lofgreen and Garrett (1968).

Body weight was measured during the experiment (every $15 \mathrm{~d}$ ) and immediately before slaughter without fasting. The slaughter procedure involved stunning the animal with a pneumatic pistol followed by exsanguination by cutting the jugular veins and carotid arteries, and the animal's blood was collected, weighed, packaged, and frozen at $-20^{\circ} \mathrm{C}$ to be reincorporated into the $\mathrm{MB}$ at grinding. Upon cessation of vital signs, the gravid uterus (uterus, placenta, placentomas, fetuses, and fetal fluid) and mammary gland were removed from the goat's body. The gastrointestinal tract (GIT) was weighed before and after emptying and flushing with water to determine empty body weight (EBW), which was calculated as the body weight at slaughter minus the weight of the contents of the GIT, bladder, and gallbladder. The MB weight was obtained by subtracting the gravid uterus and mammary gland weights from EBW. The gravid uterus, mammary gland, and MB (including empty GIT, blood, heart, lungs, spleen, and other viscera) were weighed, packaged, and frozen at $-20^{\circ} \mathrm{C}$. The gravid uterus, mammary gland, and MB were subsequently ground, homogenized, and sampled for further chemical analysis.

\section{Digestibility Trial}

To determine to the ME intake (MEI) and $\mathrm{N}$ balance (NBAL), the set of goats to be slaughtered at 140 DOP $(n=18)$ was subjected to 3 digestibility assays during pregnancy at around 80,110, and 140 DOP. While they were still on trial, the goats were adapted to the metabolic cages for $2 \mathrm{~d}$ followed by a 5 -d collection period. The goats were individually housed in metabolic cages in a randomized block design according to the feed intake treatments previously mentioned. The goats were placed in metabolism cages at 73, 103, and 133 DOP. Feed, orts, feces, and urine were collected daily over the 5-d trial. A total of $20 \%$ of the excreted feces was collected, producing a 5-d composite. Urine was collected in buckets containing $50 \mathrm{~mL}$ of $7.2 \mathrm{~N} \mathrm{H}_{2} \mathrm{SO}_{4}$, and a $10 \%$ aliquot was removed daily and frozen for further analysis.

\section{Chemical Analyses}

Samples of feed, orts, and feces were dried in a forced-air oven at $55^{\circ} \mathrm{C}$ for $72 \mathrm{~h}$. The gravid uterus, mammary gland, and MB samples were freeze-dried for $72 \mathrm{~h}$. The DM of feed, orts, and feces was determined following Association of Official Analytical Chemists (1990) procedures (method number 930.15), and the fat content of the feed ingredients was also determined following Association of Official Analytical Chemists (1990) procedures (number 920.39). Feed ingredients were analyzed for ash (complete combustion at $600^{\circ} \mathrm{C}$ for $6 \mathrm{~h}$; AOAC, 1990; method number 924.05) and NDF with amylase and without sulfite (Robertson and Van Soest, 1981). The $\mathrm{N}$ content of the feed, orts, urine, feces, gravid uterus, mammary gland, and MB were determined using Dumas combustion using a LECO FP528 LC (LECO Corp., St. Joseph, MI; Etheridge et al., 1998). Gross energy of feed, orts, urine, feces, gravid uterus, mammary gland, and MB was determined using a calorimetric bomb (Parr Instrument Co., Moline, IL).

\section{Calculations}

The MEI was estimated as the GE intake minus energy losses in feces, urine, and gases. The losses in feces 
Table 2. Equations obtained from baseline goats slaughtered at $50 \mathrm{~d}$ of pregnancy used to estimate energy and protein retention during pregnancy

\begin{tabular}{|c|c|c|c|c|c|c|c|}
\hline Dependent variable & Intercept & SEM & Slope & SEM & $\begin{array}{l}\text { Independent } \\
\text { variable }^{1}\end{array}$ & $P$-value & RMSE $^{2}$ \\
\hline Maternal BW (MBW), kg & 1.96 & 5.77 & 0.736 & 0.112 & $\mathrm{BW}_{50}{ }^{1}$ & $<0.01$ & 1.82 \\
\hline Energy, kJ & -43.0 & 111 & 13.0 & 2.74 & $\mathrm{MBW}_{50}{ }^{2}$ & $<0.01$ & 37.5 \\
\hline Protein, $g$ & -128 & 931 & 163 & 22.9 & $\mathrm{MBW}_{50}$ & $<0.01$ & 313 \\
\hline
\end{tabular}

${ }^{1} \mathrm{BW}_{50}=\mathrm{BW}$ at $50 \mathrm{~d}$ of pregnancy; $\mathrm{MBW}_{50}=\mathrm{MBW}$ at $50 \mathrm{~d}$ of pregnancy.

${ }^{2} \mathrm{RMSE}=$ root mean square error.

and urine were estimated using the digestibility data at 80 , 110 , and 140 DOP. The energy lost through gas production was estimated using the equation proposed by Blaxter and Clapperton (1965). The MEI as a proportion of GE intake was considered to be the metabolizability (qm).

Energy and $\mathrm{N}$ daily retention in the MB were estimated using the difference between the energy and protein content of the MB at slaughter (80, 110 , or $140 \mathrm{DOP})$ and the energy and protein content of the MB at $50 \mathrm{DOP}$ as estimated using the equations obtained from the baseline goats. The equations used to predict the MB energy and $\mathrm{N}$ content at $50 \mathrm{DOP}$ are presented in Table 2.

The energy requirement for maintenance during pregnancy was estimated as the nonlinear relationship between daily heat production (HP) and daily MEI according to Eq. [1]. The HP was estimated as the difference between MEI and retained energy (retained energy in the $\mathrm{MB}+$ retained energy in the pregnancy products) as follows:

$$
\mathrm{HP}_{i j k}=W_{0 j} \times \exp \left(b_{j} \times \mathrm{MEI}_{i j k}\right)+\mathrm{bl}_{k(j)}+\operatorname{error}_{i j k},
$$

in which $\mathrm{HP}_{i j k}$ is the daily $\mathrm{HP}\left(\mathrm{kJ} / \mathrm{kg} \mathrm{EBW}^{0.75}\right)$ for the $i$ th animal in the $k$ th block on the $j$ th DOP; $W_{0 j}$ is the intercept to be estimated, which was considered equal to the $\mathrm{NE}_{\mathrm{m}}$ of the $j=1,2$, or $3 \mathrm{DOP} ; b_{j}$ is the slope of the exponential equation to be estimated for each $j=1,2$, or 3 DOP; $\mathrm{MEI}_{i j k}$ is the daily MEI $\left(\mathrm{kJ} / \mathrm{kg} \mathrm{EBW}^{0.75}\right)$ for the $i$ th animal in the $k$ th block on the $j$ th DOP; $\mathrm{bl}_{k(j)}$ is the effect of block $k$ nested in DOP $j$; and error ${ }_{i j k}$ is the residual error $\sim N\left(0, \sigma_{\mathrm{e}}^{2}\right)$, in which $\sigma_{\mathrm{e}}^{2}$ is the residual variance.

The $\mathrm{NE}_{\mathrm{m}}\left(\mathrm{kJ} / \mathrm{kg} \mathrm{EBW}^{0.75}\right)$, which is equal to the fasting HP, was estimated as the intercept of the exponential equation. The requirements of ME for maintenance $\left(\mathbf{M E}_{\mathbf{m}} ; \mathrm{kJ} / \mathrm{kg} \mathrm{EBW}^{0.75}\right)$ was computed by interactively solving the exponential equation until HP was equal to MEI. The efficiency of ME utilization for maintenance $\left(\mathbf{k}_{\mathbf{m E}}\right)$ was computed as $\mathrm{NE}_{\mathrm{m}} / \mathrm{ME}_{\mathrm{m}}$.

The MP requirement for maintenance $\left(\mathbf{M P}_{\mathbf{m}}\right)$ was estimated using regression of the retained protein on $\mathrm{MB}$ and pregnancy products $\left(\mathrm{g} / \mathrm{kg} \mathrm{EBW}^{0.75}\right)$ against MP intake (MPI; $\mathrm{g} / \mathrm{kg} \mathrm{EBW}^{0.75}$ ). The MPI was estimated using the chemical composition of the diet according to Luo et al. (2004a). The $\mathrm{MP}_{\mathrm{m}}$ was obtained by assuming the retained protein on $\mathrm{MB}$ and pregnancy products as equal to 0 .

$$
\mathrm{RP}_{i j k}=a_{j}+b_{j} \times \mathrm{MPI}_{i j k}+\mathrm{bl}_{k(j)}+\text { error }_{i j k},
$$

in which $\mathrm{RP}_{i j k}$ is the daily retained protein in $\mathrm{MB}$ and pregnancy products estimated using the comparative slaughter technique $\left(\mathrm{g} / \mathrm{kg} \mathrm{EBW}^{0.75}\right)$ for the $i$ th animal in the $k$ th block on the $j$ th DOP; $a_{j}$ is the intercept representing the endogenous and metabolic losses of the $j=1,2$, or $3 \mathrm{DOP} ; b_{j}$ is the slope of regression of the $j=$ 1,2 , or 3 DOP; MPI $_{i j k}$ is the daily MPI $\left(\mathrm{g} / \mathrm{kg} \mathrm{EBW}^{0.75}\right)$ for the $i$ th animal in the $k$ th block on the $j$ th DOP; $\mathrm{bl}_{k(j)}$ is the effect of block $k$ nested in DOP $j$; and error ${ }_{i j k}$ is the residual error $\sim N\left(0, \sigma_{\mathrm{e}}^{2}\right)$.

The daily net protein requirement for maintenance $\left(\mathbf{N P}_{\mathbf{m}}\right)$ during pregnancy was estimated using a linear regression of retained $\mathrm{N}$ against $\mathrm{N}$ intake $(\mathrm{g} / \mathrm{kg}$ $\mathrm{EBW}^{0.75}$; Eq. [2]). The retained $\mathrm{N}$ was estimated using the comparative slaughter ( $\mathrm{N}$ retained on $\mathrm{MB}$ and pregnancy products) and NBAL (from the digestibility trial) techniques. The intercept of the regression was assumed to be the endogenous and metabolic losses of $\mathrm{N}$, which are assumed to represent the net $\mathrm{N}$ requirement for maintenance. This value multiplied by a factor of 6.25 provided the estimate of $\mathrm{NP}_{\mathrm{m}}$.

$$
\mathrm{RN}_{i j k}=a_{j}+b_{j} \times \mathrm{NI}_{i j k}+\mathrm{bl}_{k(j)}+\text { error }_{i j k},
$$

in which $\mathrm{RN}_{i j k}$ is the daily retained $\mathrm{N}$ estimated using the comparative slaughter or NBAL $\left(\mathrm{g} / \mathrm{kg} \mathrm{EBW}{ }^{0.75}\right)$ technique for the $i$ th animal in the $k$ th block on the $j$ th DOP; $a_{j}$ is the intercept representing the endogenous and metabolic losses of the $j=1,2$, or 3 DOP; $b_{j}$ is the slope of regression of the $j=1,2$, or $3 \mathrm{DOP} ; \mathrm{NI}_{i j k}$ is the daily $\mathrm{N}$ intake $\left(\mathrm{g} / \mathrm{kg} \mathrm{EBW}{ }^{0.75}\right)$ for the $i$ th animal in the $k$ th block on the $j$ th DOP; $\mathrm{bl}_{k(j)}$ is the effect of block $k$ nested in DOP $j$; and error ${ }_{i j k}$ is the residual error $\sim N\left(0, \sigma_{\mathrm{e}}^{2}\right)$. 
The efficiency of MP utilization for maintenance ( $\left.\mathbf{k}_{\mathbf{m P}}\right)$ was computed as $\mathrm{NP}_{\mathrm{m}} / \mathrm{MP}_{\mathrm{m}}$.

The efficiency of ME utilization for pregnancy $\left(\mathbf{k}_{\mathbf{p E}}\right)$ and the efficiency of MP utilization for pregnancy $\left(\mathbf{k}_{\mathbf{p P}}\right)$ were estimated using regressions of energy and protein daily retention in the MB plus pregnancy products against daily MEI and MPI above maintenance. For this calculation, we used the $\mathrm{ME}_{\mathrm{m}}$ and $\mathrm{MP}_{\mathrm{m}}$ determined using Eq. [1] and [2]. These regressions were set with an intercept equal to 0 , and the $\mathrm{k}_{\mathrm{pE}}$ and $\mathrm{k}_{\mathrm{pP}}$ were obtained using the inverse of slope for pregnancy product retention (Eq. [4]). In this study, we did not consider the slope for the MB as an efficiency because the energy and protein retention are a result of the deposition and mobilization processes and we were not able to quantify them separately. Therefore, there was no interpretation of the slope as related to retention in the MB.

$$
\begin{aligned}
\mathrm{IAM}_{i j k}= & a_{j} \times \mathrm{RMB}_{i j k}+b_{j} \times \mathrm{RPP}_{i j k} \\
& +\mathrm{bl}_{k(j)}+\text { error }_{i j k},
\end{aligned}
$$

in which $\mathrm{IAM}_{i j k}$ is the intake of ME above maintenance or MP above maintenance for the $i$ th animal in the $k$ th block on the $j$ th DOP; $a_{j}$ is the slope related to the retention on the $\mathrm{MB}$ of the $j=1,2$, or $3 \mathrm{DOP} ; \mathrm{RMB}_{i j k}$ is the retained energy or protein on the $\mathrm{MB}$ for the $i$ th animal in the $k$ th block in the $j$ th DOP; $b_{j}$ is the slope related to the retention on pregnancy products of the $j=1,2$, or 3 $\mathrm{DOP} ; \mathrm{RPP}_{i j k}$ is the retained energy or protein on pregnancy products for the $i$ th animal in the $k$ th block on the $j$ th DOP; $\mathrm{bl}_{k(j)}$ is the effect of block $k$ nested in DOP $j$; and error $r_{i j k}$ is the residual error $\sim N\left(0, \sigma_{\mathrm{e}}^{2}\right)$.

\section{Statistical Analyses}

The regression equations obtained from the baseline goats to predict the MB energy and protein content at 50 DOP were obtained using the MIXED procedure of SAS (version 9.4; SAS Inst. Inc., Cary, NC). Statistical significance was declared at $P<0.05$. The slopes and intercepts of each equation were estimated using the ESTIMATE statement of the MIXED procedure of SAS.

The results obtained from the digestibility trial were evaluated in a completely randomized block design with repeated measures over time. The data were analyzed as mixed models with fixed effects of level of feed restriction $(2 \mathrm{df})$, days of gestation $(2 \mathrm{df})$, and the interaction of these factors and the random effects of block and residual error using the MIXED procedure of SAS (version 9.4). The covariance matrix that best fit the data according to the corrected Akaike information criterion (AICc) was selected. Orthogonal contrasts were performed to verify linear or quadratic trends. Statistical significance was declared at $P<0.05$.

The results of $\mathrm{MB}$ composition were evaluated in a randomized block design as mixed models with the fixed effects of level of feed restriction ( $2 \mathrm{df}$ ), days of gestation ( $2 \mathrm{df})$, and the interaction of these factors and the random effects of block and residual error using the MIXED procedure of SAS (version 9.4). Orthogonal contrasts were performed to verify linear or quadratic trends. Statistical significance was declared at $P<0.05$.

Maintenance requirements and efficiencies were obtained by fitting nonlinear equations (i.e., Eq. [1] to Eq. [4]) to the data using the \%NLINMIX macro of SAS (version 9.4), considering DOP as a fixed effect. The between-blocks variability was modeled by introducing a parameter $\mu$ into equation parameters $\left(W_{0}\right.$ or $\left.a\right)$. The block effect was included in the random statement (subject $=$ block [days]) using Variance Components as the variance-covariance matrix structure (Littell et al., 2006). The residual variance was modeled using the power-ofthe-mean variance function to obtain a homogeneous variance of the residuals (Littell et al., 2006). Restricted maximum likelihood or maximum likelihood was used as the method of estimation, and the choice between them was based on the AICc value. The equations were fitted using a linearization around the empirical best linear unbiased prediction, which was based on the parameter estimation procedure of Lindstrom and Bates (1990). Parameters of the models for each DOP were compared using the CONTRAST statement. When there was no effect of DOP on the equations parameters, the fixed effect of DOP was removed from the model. Differences between parameters were declared significant at $P<0.05$.

Monte Carlo simulations were performed to obtain the lower $90 \%$ confidence interval (LCI) and upper $90 \%$ confidence interval (UCI) of the $\mathrm{ME}_{\mathrm{m}}, \mathrm{NE}_{\mathrm{m}}, \mathrm{MP}_{\mathrm{m}}$, and $\mathrm{NP}_{\mathrm{m}}$ estimates. We calculated 10,000 simulated values for each of these energy and protein requirements with a multivariate normal distribution for the parameters and error estimates using the algorithm of Fan et al. (2002).

\section{RESULTS AND DISCUSSION}

\section{Digestibility and Maternal Body composition}

The DMI linearly decreased as pregnancy progressed $(P<0.01)$ as well as with increasing feed restriction $(P<0.01$; Table 3$)$. Goats used in this study were carrying twins, which likely led to greater rumen compression as the pregnancy progressed than at the beginning of pregnancy, resulting in a considerable decrease in DMI (Forbes, 2007). In addition, with the progress of pregnancy, feed intake is affected by an increase in the levels of plasma estrogen released from the placenta, increasing the estrogen-to-progesterone ratio (Grum- 
mer, 1995). Although the decrease in feed intake led us to expect an increase in nutrient digestibility, this was not observed for GE and CP digestibility $(69.6 \pm 6.28$ and $73.2 \pm 4.78$, respectively), which did not change with DOP or feed restriction. However, our results are in accordance with studies performed on pregnant ewes limit-fed chopped alfalfa hay and beef cows fed ad libitum, which also reported no change in apparent total tract DM digestibility with advancing pregnancy (Gunter et al., 1990; Hanks et al., 1993).

The qm was greatest at $0 \%$ of feed restriction and decreased at a decreasing rate $(P=0.03)$ with feed restriction; qm was $63.3 \pm 2.16,55.7 \pm 2.35$, and $58.2 \pm$ $2.30 \%$ at 0,20 , and $40 \%$ of feed restriction, respectively. A significant interaction between DOP and feed restriction was observed for energy balance; at 80 and 110 DOP, goats fed ad libitum showed the greatest energy balance; however, at $140 \mathrm{DOP}$, the energy balance was similar among goats irrespective of feed restriction $(P=0.025$; Table 3$)$. The NBAL linearly decreased as feed restriction increased $(P<0.05$; Table 3$)$ and was $6.39 \pm 2.13,1.36 \pm 2.40$, and $-0.468 \pm 2.32 \mathrm{~g} / \mathrm{d}$ at 0 , 20 , and $40 \%$ of feed restriction, respectively. In addition, losses of energy and $\mathrm{N}$ in the urine (\% of energy and $\mathrm{N}$ intake, respectively) linearly increased $(P=0.02)$ in these females as feed restriction increased. Irrespective of DOP, pregnant goats subjected to 0,20 , and $40 \%$ feed restriction showed, on average, energy losses in urine of $2.53,2.70$, and $3.72 \%$ energy intake, respectively, and $\mathrm{N}$ losses in urine of $62.5,67.6$, and $92.6 \% \mathrm{~N}$ intake, respectively. This may explain the decrease in qm and NBAL with feed restriction, which could also indicate a mobilization of MB reserves. Goats at 140 DOP showed lighter MB weight than goats at 80 and 110 DOP, especially those fed at $40 \%$ feed restriction $(P=0.011$; Table 4). On the other hand, protein, fat, and energy MB composition were not affected by DOP and feed restriction $(P>0.05$; Table 4$)$. Therefore, it is clear that goats decreased their body tissues composition proportionally to $\mathrm{MB}$ weight. In addition, a linear decrease was observed in the protein and energy retention on the MB with the increase of feed restriction $(P<0.05$; Table 4$)$. Therefore, these changes in the energy and protein retentions confirm the mobilization of MB reserves.

Through these results, we can infer that due to the high protein and energy demand of the pregnancy products, the female mobilizes body reserves when the diet supply does not meet those requirements (Bauman and Currie, 1980; McNeill et al., 1997). Therefore, as digestibility of CP and GE did not increase with feed restriction, mobilization of maternal reserves to meet pregnancy demands was needed, leading to the decrease in qm, energy balance, and NBAL. In addition,

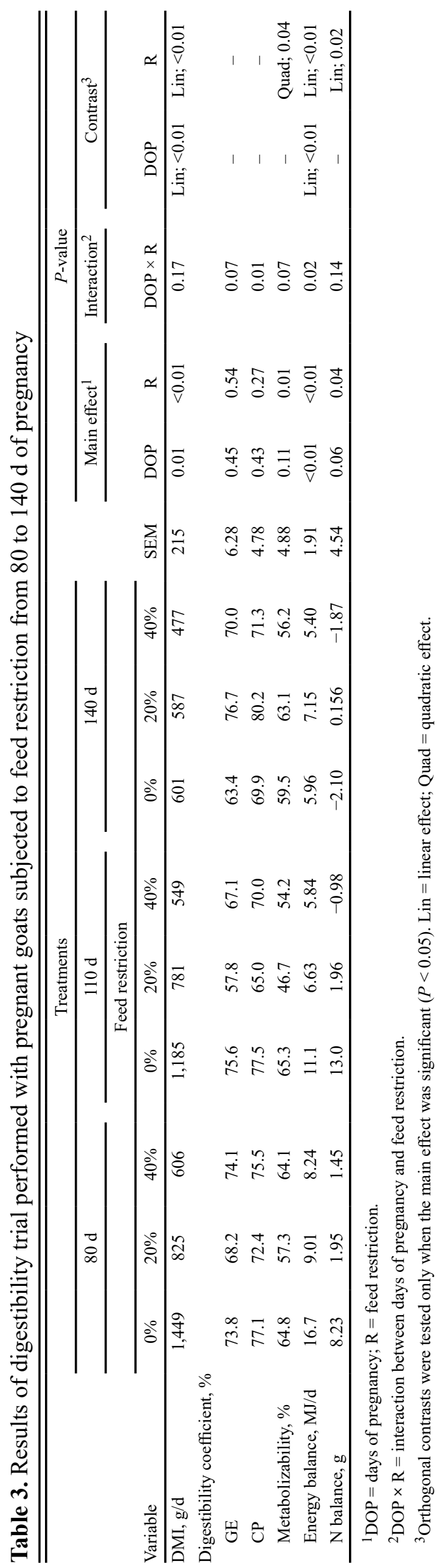


we also suggest that more studies are needed to better elucidate energy and protein partition in pregnant does.

In addition, protein retention linearly decreased with the progress of pregnancy $(P<0.01)$. Irrespective of feed restriction, a negative retention at 140 DOP was observed, indicating that not only feed restriction but also the progress of pregnancy affects protein mother reserves. This can be due to the decrease of DMI that may reduce the microbial protein synthesis, decreasing the AA supply for the MB. However, this decrease of protein supply with the progress of pregnancy affected NBAL less than feed restriction.

\section{Energy Requirements for Maintenance}

There was no effect of DOP on the intercepts and slopes of the equations for estimation of energy requirements for maintenance during pregnancy $(P>$ 0.05), and therefore, a unique equation (Eq. [5]) was applied from 80 to $140 \mathrm{DOP}$ (Fig. 1). The $\mathrm{NE}_{\mathrm{m}}$ was $197\left(\mathrm{~kJ} / \mathrm{kg} \mathrm{EBW}^{0.75}\right)$ with an LCI and UCI of 120 and $210 \mathrm{~kJ} / \mathrm{kg} \mathrm{EBW}{ }^{0.75}$, respectively. The $\mathrm{ME}_{\mathrm{m}}$, when MEI was set equal to HP, was $315 \mathrm{~kJ} / \mathrm{kg} \mathrm{EBW}^{0.75}$; the LCI and UCI for $\mathrm{ME}_{\mathrm{m}}$ were 169 and $330 \mathrm{~kJ} / \mathrm{kg}$ $\mathrm{EBW}^{0.75}$, respectively.

$$
\mathrm{HP}=197 \pm 22.6 \times \exp (0.00149 \pm 0.00018 \times \mathrm{MEI}),[5]
$$

in which HP is the daily HP $\left(\mathrm{kJ} / \mathrm{kg} \mathrm{EBW}^{0.75}\right)$ and MEI is the daily MEI $\left(\mathrm{kJ} / \mathrm{kg} \mathrm{EBW}^{0.75}\right.$; root mean square error $[\mathbf{R M S E}]=16.5, \mathrm{AICc}=554, \sigma_{\mathrm{e}}^{2}=272$ ).

The $\mathrm{NE}_{\mathrm{m}}$ for mature goats reported by the Agricultural and Food Research Council (1998) of $315 \mathrm{~kJ} / \mathrm{kg}$ BW 0.75 is greater than that observed in our study. In addition, the observed $\mathrm{NE}_{\mathrm{m}}\left(197 \mathrm{~kJ} / \mathrm{kg} \mathrm{EBW} \mathrm{EB}^{0.75}\right)$ was also lower than those reported for sheep of 269 (Rattray et al., 1973) and $259 \mathrm{~kJ} / \mathrm{kg} \mathrm{BW}^{0.75}$ (Blaxter, 1967). The $\mathrm{ME}_{\mathrm{m}}$ found in this study were considerably lower than those previously reported for goats: $400 \mathrm{~kJ} / \mathrm{kg} \mathrm{BW}^{0.75}$ for pregnant and lactating goats up to $8 \mathrm{mo}$ of age (Voicu et al., 1993), $438 \mathrm{~kJ} / \mathrm{kg} \mathrm{BW}^{0.75}$ for mature goats (AFRC, 1998), $462 \mathrm{~kJ} / \mathrm{kg} \mathrm{BW}^{0.75}$ for mature goats over $18 \mathrm{mo}$ of age (Luo et al., 2004b), $501 \mathrm{~kJ} / \mathrm{kg} \mathrm{BW}^{0.75}$ for mature dairy goats (NRC, 2007), and $542 \mathrm{~kJ} / \mathrm{kg} \mathrm{BW}^{0.75}$ for mature and growing goats (Salah et al., 2014).

To our knowledge, this is the first study measuring requirements for maintenance during pregnancy in goats, and no standard values of $\mathrm{NE}_{\mathrm{m}}$ or $\mathrm{ME}_{\mathrm{m}}$ have been established for goats of similar condition to allow comparison. Before the estimation of $\mathrm{NE}_{\mathrm{m}}$ (i.e., using Eq. [5]), we tested the effect of feed restriction on the parameters of Eq. [5], and they were not significantly affected by feed restriction $(P>0.05)$, which means

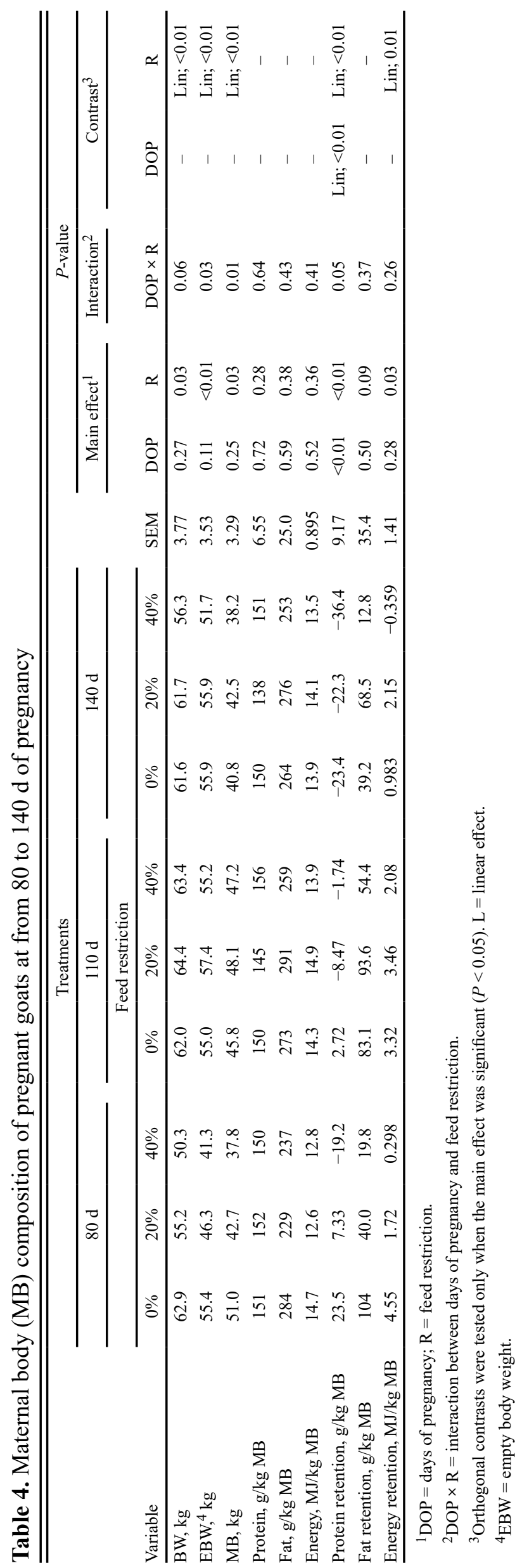




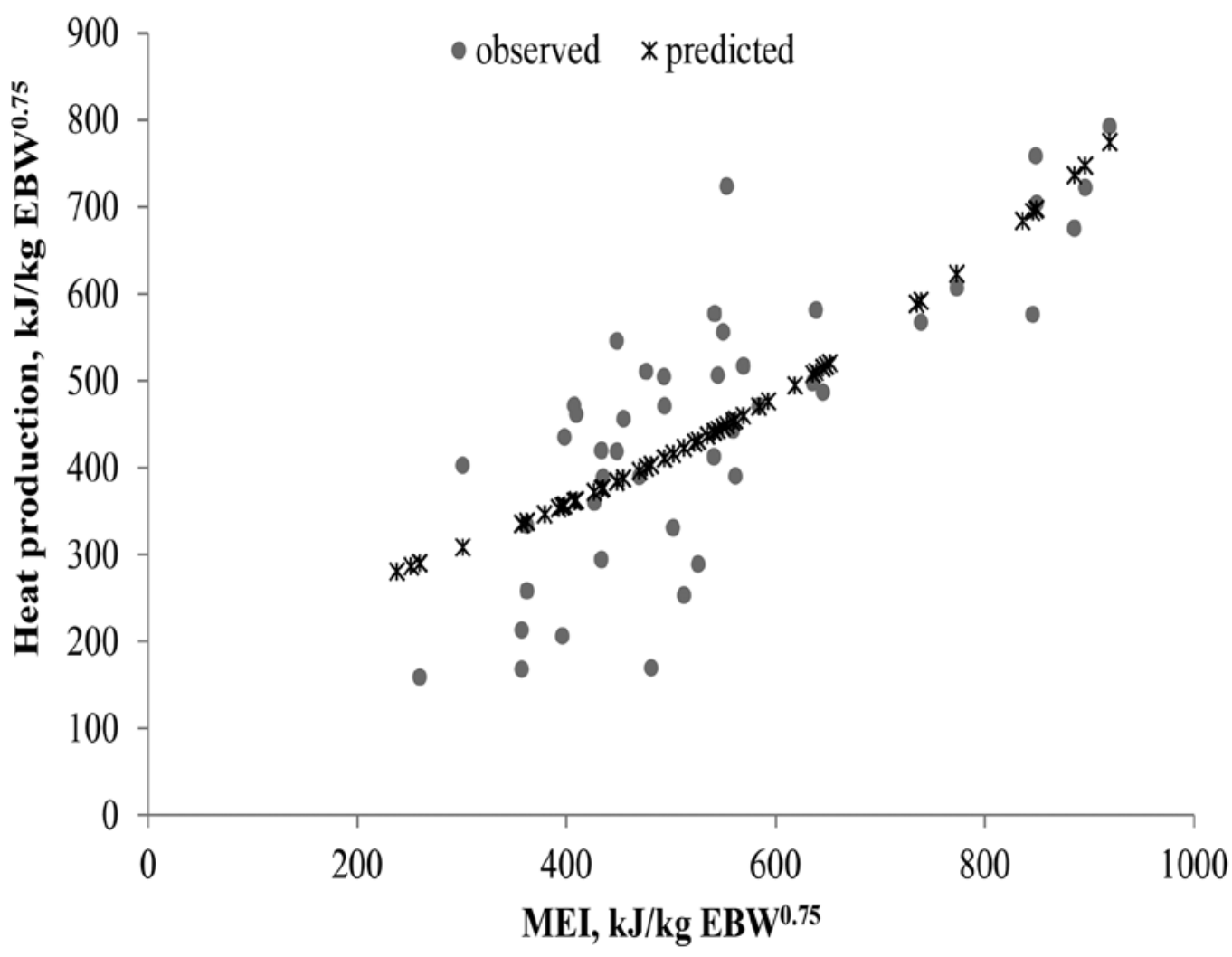

Figure 1. Relationship between daily ME intake (MEI; kJ/kg empty body weight $[\mathrm{EBW}]^{0.75}$ ) and daily heat production $\left(\mathrm{HP} ; \mathrm{kJ}^{\prime} / \mathrm{kg} \mathrm{EBW}{ }^{0.75}\right)$ of goats during pregnancy (Eq. [5]; HP $=197 \pm 22.6 \times \exp (0.00149 \pm 0.00018 \times$ MEI)

that feed restriction did not affect the fast HP of goats in this study. Although some studies showed an effect of feeding level on FHP in lambs and calves (Ferrell et al., 1986; Labussière et al., 2011), this was not observed in our study using adult female goats. Our experiment was not designed to evaluate the feeding level effect on FHP (i.e., comparative slaughter technique), making further discussions about it difficult, and therefore, we suggest that more studies on this subject are still needed with adult ruminants, especially pregnant goats.

The low energy requirements observed in this study may be related to the decrease in basal metabolic rate (BMR) observed with aging. Graham et al. (1974) showed that the BMR of adult sheep declines $8 \%$ per annum with aging. According to these authors' findings, the $\mathrm{NE}_{\mathrm{m}}$ of a 4 -yr-old sheep is $205 \mathrm{~kJ} / \mathrm{kg} \mathrm{BW}^{0.75}$, which is close to our findings and also in accordance with the age of goats used in our experiment, which were at approximately their third or fourth parturition. Aging has also been reported to decrease BMR in humans, and BMR can be more sharply decreased when associated with a tropical climate. With regard to the climate, our experiment was performed in a region with climate classification "Aw" (Rolim et al., 2007) and is characterized as tropical with a wet summer season and dry winter season, with an average annual minimum temperature of $15.7^{\circ} \mathrm{C}$ and maximum temperature of $27.7^{\circ} \mathrm{C}$. In accordance with our findings, preliminary results of a study conducted at the same facility with mature goats using respirometry reported fasting HP of $183 \mathrm{~kJ} / \mathrm{kg} \mathrm{BW}{ }^{0.75}$ (Fernandes et al., 2016), which is close to our result for $\mathrm{NE}_{\mathrm{m}}$. Therefore, based on this discussion, we can affirm that age also influences energy requirements for maintenance in goats; however, more studies related to the influence of climate on the energy requirements of goats are still needed for better understanding of this aspect.

\section{Protein Requirements for Maintenance}

The $\mathrm{NP}_{\mathrm{m}}$ estimated using $\mathrm{N}$ retention in the $\mathrm{MB}$ and pregnancy products, obtained using the comparative slaughter technique and regressed against $\mathrm{N}$ intake, provided an estimate of total endogenous losses of $1.38 \pm 0.512 \mathrm{~g} / \mathrm{kg} \mathrm{EBW} \mathrm{E}^{0.75}$ (Eq. [6]; $P=0.003$ ), which was similar among DOP $(P>0.05)$. The LCI and UCI for $\mathrm{NP}_{\mathrm{m}}$ were 0.488 and $2.44 \mathrm{~g} / \mathrm{kg} \mathrm{EBW}^{0.75}$, respectively. Furthermore, the $\mathrm{NP}_{\mathrm{m}}$ estimated using the NBAL regressed against $\mathrm{N}$ intake during the digestibility trials was $2.49 \pm 0.594 \mathrm{~g} / \mathrm{kg} \mathrm{EBW}^{0.75}$ (Eq. [7]; $P<0.01)$; this was similar among DOP $(P>0.05)$ and was greater than the $\mathrm{NP}_{\mathrm{m}}$ estimated using the comparative slaughter technique. 
For the comparative slaughter technique,

$$
\mathrm{RN}_{\mathrm{CS}}=-0.222 \pm 0.082+0.212 \pm 0.059 \mathrm{NI} \text {, }
$$

in which $\mathrm{RN}_{\mathrm{CS}}$ is the daily retained $\mathrm{N}$ on the $\mathrm{MB}$ and pregnancy products $\left(\mathrm{g} / \mathrm{kg} \mathrm{EBW}^{0.75}\right)$ obtained using the comparative slaughter technique $\left(\mathrm{g} / \mathrm{kg} \mathrm{EBW}^{0.75}\right)$ and NI is the daily NI $\left(\mathrm{g} / \mathrm{kg} \mathrm{EBW}^{0.75} ; n=58, \mathrm{RMSE}=\right.$ $\left.0.159, \mathrm{AICc}=-32.8, \sigma_{\mathrm{e}}^{2}=0.0254\right)$.

For the NBAL technique,

$$
\mathrm{RN}_{\mathrm{NBAL}}=-0.399 \pm 0.095+0.605 \pm 0.093 \mathrm{NI}
$$

in which $\mathrm{RN}_{\mathrm{NBAL}}$ is the daily retained $\mathrm{N}$ using the NBAL technique $\left(\mathrm{g} / \mathrm{kg} \mathrm{EBW}^{0.75}\right)$ and NI is the daily $\mathrm{NI}\left(\mathrm{g} / \mathrm{kg} \mathrm{EBW}{ }^{0.75} ; n=18, \mathrm{RMSE}=0.229, \mathrm{AICc}=8.2\right.$, $\left.\sigma_{\mathrm{e}}^{2}=0.0528\right)$.

The $\mathrm{MP}_{\mathrm{m}}$ was not affected by DOP, and when retained protein was set equal to zero, a daily requirement of $3.22 \mathrm{~g} \mathrm{MP} / \mathrm{kg} \mathrm{EBW}^{0.75}$ was found (Eq. [8]; $P<0.01)$. The LCI and UCI for $\mathrm{MP}_{\mathrm{m}}$ were 1.36 and $4.39 \mathrm{~g} / \mathrm{kg} \mathrm{EBW}^{0.75}$, respectively.

$$
\mathrm{RPMB}=-0.436 \pm 0.184+0.135 \pm 0.0355 \times \mathrm{MPI},
$$

in which RPMB is the daily retained protein on MB and pregnancy products $\left(\mathrm{g} / \mathrm{kg} \mathrm{EBW}^{0.75}\right)$ and MPI is the daily MPI $\left(\mathrm{g} / \mathrm{kg} \mathrm{EBW}{ }^{0.75} ; \mathrm{RMSE}=1.92, \mathrm{AICc}=\right.$ $\left.125, \sigma_{\mathrm{e}}^{2}=3.72\right)$.

The $\mathrm{NP}_{\mathrm{m}}$ appears to depend on the method of assessment used. It has been reported that for many reasons, the NBAL method overestimates $\mathrm{NP}_{\mathrm{m}}$ for goats (Almeida et al., 2015a). In accordance, our result of $\mathrm{NP}_{\mathrm{m}}$ as estimated using NBAL was practically double that determined using the comparative slaughter technique. In addition, it is noteworthy that the requirements found using the NBAL method resulted in greater variation for the parameters than those found using the comparative slaughter method. However, the $\mathrm{NP}_{\mathrm{m}}$ estimated herein using NBAL is similar to the $\mathrm{NP}_{\mathrm{m}}$ reported by the Agricultural and Food Research Council $(1998 ; 2.19 \mathrm{~g} / \mathrm{kg}$ $\left.\mathrm{BW}^{0.75}\right)$, which is a feeding system that bases its recommendations on studies of endogenous urinary $\mathrm{N}$ plus part of the metabolic fecal $\mathrm{N}$ and dermal losses.

On the other hand, the $\mathrm{NP}_{\mathrm{m}}$ determined using the comparative slaughter technique in the present study was slightly lower than those reported for growing Saanen goats from 20 to $45 \mathrm{~kg} \mathrm{BW}$ (1.63 and $1.46 \mathrm{~g} / \mathrm{kg} \mathrm{BW}^{0.75}$; Almeida et al., 2015a; Ferreira et al., 2015), which were also obtained using this technique. Assuming an average relationship of $\mathrm{BW}^{0.75}: \mathrm{EBW}^{0.75}$ of 1.09 as observed in our study, the $\mathrm{MP}_{\mathrm{m}}$ was $2.95 \mathrm{~g} / \mathrm{kg} \mathrm{BW}^{0.75}$, which is close to the $3.07 \mathrm{~g} / \mathrm{kg} \mathrm{BW}^{0.75}$ reported for growing goats (Luo et al., 2004a) and $2.85 \mathrm{~g} / \mathrm{kg} \mathrm{BW}^{0.75}$ for mature does of
$50 \mathrm{~kg} \mathrm{BW}$ (NRC, 2007). Comparing our results for $\mathrm{MP}_{\mathrm{m}}$ with the available literature on growing goats, contrary to what happens with energy, it is clear that aging has little to no influence on phenomena related to protein requirements for maintenance. There is no evidence in the literature that $\mathrm{NP}_{\mathrm{m}}$ decreases with aging, but our findings suggest that this subject deserves further attention. Conversely, it is known that pregnancy products' growth cannot be achieved solely through the feed ingested and that pregnant goats experience a progressive decrease in protein retention in their bodies during pregnancy whereas urea recycling increases (Castagnino et al., 2015). Although the MB can suffer such adjustments to protein metabolism to ensure pregnancy success, the results of this study show that these physiological changes during pregnancy did not affect $\mathrm{NP}_{\mathrm{m}}$ or $\mathrm{MP}_{\mathrm{m}}$. Furthermore, due to the greater number of observations and low error, the results of $\mathrm{NP}_{\mathrm{m}}$ obtained using the comparative slaughter technique seem to give a more reliable reference value for adoption in mature goats.

\section{Efficiencies of Energy and Protein Use for Maintenance and Pregnancy}

The $\mathrm{k}_{\mathrm{mE}}$ found in this study was 0.63 . The $\mathrm{k}_{\mathrm{mE}}$ is related to diet quality (ARC, 1980), and in studies using a similar diet, similar values of 0.63 (Almeida et al., 2015b) and 0.65 (Figueiredo et al., 2016) were observed. However, using the equation proposed by the Agricultural and Food Research Council (1998), which is based on qm, our simulation resulted in a $\mathrm{k}_{\mathrm{mE}}$ of 0.72 (an average qm of 0.63 for animals fed ad libitum; Table 3 ), which was approximately $20 \%$ greater than that obtained in our study. This finding suggests that the environment may influence diet energy use, because irrespective of physiological status, we observed similar $\mathrm{k}_{\mathrm{mE}}$ with similar diets, which were lower than the value predicted by the Agricultural and Food Research Council (1998) approach.

Using the results obtained using the comparative slaughter technique, we found a $\mathrm{k}_{\mathrm{mP}}$ of 0.43 . There appear to be no reports on $\mathrm{k}_{\mathrm{mP}}$ in goats. The Agricultural and Food Research Council (1998) adopts an efficiency of absorbed AA of 1.0, and the NRC (2001) adopts an efficiency of converting MP to net protein for maintenance of 0.67 for dairy cows, which is close to the 0.70 adopted by the Commonwealth Scientific and Industrial Research Organisation (1990). However, there is huge variability among these efficiency values, which also are much greater than the value observed in this study. Some of these differences may be related to the experimental techniques used to estimate the $\mathrm{k}_{\mathrm{mP}}$ as well as to differences related to the animals' species or physiological stage. Therefore, we suggest 
Table 5. Equations to estimate efficiency of energy and protein use for pregnancy (efficiency is estimated using the inverse of slope for pregnancy products retention) at 80,110, and $140 \mathrm{~d}$ of pregnancy (DOP)

\begin{tabular}{|c|c|c|}
\hline \multirow[b]{2}{*}{ DOP } & \multicolumn{2}{|c|}{ Equations $^{1}$} \\
\hline & $\begin{array}{c}\text { Energy } \\
\left(\mathrm{RMSE}=57.5, \mathrm{AICc}=669, \sigma_{\mathrm{e}}^{2}=3,308\right)\end{array}$ & $\begin{array}{c}\text { Protein } \\
\left(\mathrm{RMSE}=1.92, \text { AICc }=227, \sigma_{\mathrm{e}}^{2}=3.70\right)\end{array}$ \\
\hline $80 \mathrm{~d}$ & $\mathrm{MEI}_{\mathrm{am}}=0.250 \pm 0.157 \mathrm{REMB}+17.3 \pm 3.70 \times \mathrm{REPP}$ & $\mathrm{MPI}_{\mathrm{am}}=0.588 \pm 0.225 \mathrm{RPMB}+8.20 \pm 1.26 \times \mathrm{RPPP}$ \\
\hline $110 \mathrm{~d}$ & $\mathrm{MEI}_{\mathrm{am}}=0.250 \pm 0.157 \mathrm{REMB}+10.2 \pm 2.36 \times \mathrm{REPP}$ & $\mathrm{MPI}_{\mathrm{am}}=0.588 \pm 0.225 \mathrm{RPMB}+4.79 \pm 0.860 \times \mathrm{RPPP}$ \\
\hline $140 \mathrm{~d}$ & $\mathrm{MEI}_{\mathrm{am}}=0.250 \pm 0.157 \mathrm{REMB}+5.38 \pm 1.38 \times \mathrm{REPP}$ & $\mathrm{MPI}_{\mathrm{am}}=0.588 \pm 0.225 \mathrm{RPMB}+2.35 \pm 0.622 \times \mathrm{RPPP}$ \\
\hline \multirow{2}{*}{$\begin{array}{l}\text { Contrasts for the } \\
\text { equation parameters }{ }^{2}\end{array}$} & \multicolumn{2}{|c|}{$P$-value } \\
\hline & Equations for energy & Equations for protein \\
\hline MB at $80 \mathrm{~d}$ vs. SMB at $110 \mathrm{~d}$ & 0.98 & 0.71 \\
\hline MB at $80 \mathrm{~d}$ vs. SMB at $140 \mathrm{~d}$ & 0.91 & 0.15 \\
\hline MB at $110 \mathrm{~d}$ vs. SMB at $140 \mathrm{~d}$ & 0.94 & 0.35 \\
\hline PP at $80 \mathrm{~d}$ vs. SPP at $110 \mathrm{~d}$ & 0.07 & 0.03 \\
\hline PP at $80 \mathrm{~d}$ vs. SPP at $140 \mathrm{~d}$ & $<0.01$ & $<0.01$ \\
\hline PP at $110 \mathrm{~d}$ vs. SPP at $140 \mathrm{~d}$ & 0.08 & 0.03 \\
\hline
\end{tabular}

${ }^{1}$ Based on Eq. [4] of Material and Methods. $\mathrm{MEI}_{\mathrm{am}}=\mathrm{ME}$ intake above maintenance; REMB = retained energy on maternal body; REPP $=$ retained energy on pregnancy products; $\mathrm{MPI}_{\mathrm{am}}=\mathrm{MP}$ intake above maintenance; $\mathrm{RPMB}=$ retained protein on maternal body; $\mathrm{RPPP}=$ retained protein on pregnancy products; $\mathrm{RMSE}=$ root mean square error; $\mathrm{AICc}=$ corrected Akaike information criterion; $\sigma_{\mathrm{e}}{ }^{2}=$ residual variance.

${ }^{2} \mathrm{SMB}=$ slope for maternal body; $\mathrm{SPP}=$ slope for pregnancy products. The intercept of both equations was similar among DOP $(P>0.05)$.

that more studies related to efficiency of protein use in maintenance are still needed, especially for goats.

The $\mathrm{k}_{\mathrm{pE}}$ and $\mathrm{k}_{\mathrm{pP}}$ increased with the progress of pregnancy and were 0.058 and 0.12 , respectively, at 80 DOP; 0.10 and 0.21 , respectively, at $110 \mathrm{DOP}$; and 0.19 and 0.43 , respectively, at $140 \mathrm{DOP}$ (Table 5). These results show that efficiency is lower in earlier pregnancy than at term. It is known that the association of hormonal actions and rumen compression by the pregnant uterus leads to a decrease in pregnant females' capacity for DMI during the second half of pregnancy (from, on average, $76 \mathrm{~d}$ on for goats; Forbes, 2007) at the same time that pregnancy products increase their protein and energy growth rate (Härter et al., 2016). Therefore, as we observed an increase at an increased rate of $\mathrm{k}_{\mathrm{pE}}$ and $\mathrm{k}_{\mathrm{pP}}$, it is plausible to assume that the MB metabolism became more efficient at nutrient distribution to the pregnancy products during the second half of pregnancy, which was the period evaluated in this study.

Additionally, our results include energy and protein deposition in the mammary gland, whereas the Agricultural and Food Research Council (1998) adopted a $\mathrm{k}_{\mathrm{pE}}$ of 0.13 for $63 \mathrm{~d}$ after conception until the end of pregnancy for goats, and this value was obtained based only on the energy required for conceptus growth and ignores that required for mammary gland growth, which could result in a lower efficiency value. Rattray et al. (1974) reported a $\mathrm{k}_{\mathrm{pE}}$ (which includes the conceptus and mammary gland energy demand) of 0.16 for sheep at 125 and $140 \mathrm{DOP}$, and these reports are very close to our $\mathrm{k}_{\mathrm{pE}}$ result observed at 140 DOP.

Our results for $\mathrm{k}_{\mathrm{pP}}$ at the end of pregnancy are also close to those reported for conceptus growth in preg- nant sheep (0.40; Jarrige, 1989) and in cows (0.33; NRC, 2001), which do not include mammary gland protein accretion. However, there is no information about the period that these $\mathrm{k}_{\mathrm{pP}}$ reported by the INRA and the NRC are based on. To our knowledge, this is the first study to identify these differences in protein and energy efficiencies of utilization for pregnancy during the second half of pregnancy, and there is no such available information in the literature to allow further comparison.

The $\mathrm{k}_{\mathrm{pE}}$ and $\mathrm{k}_{\mathrm{pP}}$ results suggest that the retention process is less efficient than the energy and protein efficiencies for maintenance. However, as shown in Fig. 2 , the accretion of energy and protein in the pregnancy products is not directly related to intake level over maintenance but results mainly from maternal physiological adjustments. This is in accordance with the report by Bauman and Currie (1980), which draws attention to the fact that this apparent inefficiency is derived from ignoring the sizeable cost of maintenance of products of conception and that fetal growth and development are energetically comparable to other productive processes (i.e., growth and milk production). In addition, pregnancy imposes significant maternal adaptations, and homeorhetic controls are involved in meeting energy and nutrient requirements ahead of the increase in nutrient demands by the pregnancy products at the same time that the fetus's nutrient uptake gains a certain degree of autonomy (Bauman and Currie, 1980). Therefore, such low values for $\mathrm{k}_{\mathrm{pE}}$ and $\mathrm{k}_{\mathrm{pP}}$ are reported because pregnancy products' growth is irrespective of energy and protein intake. 

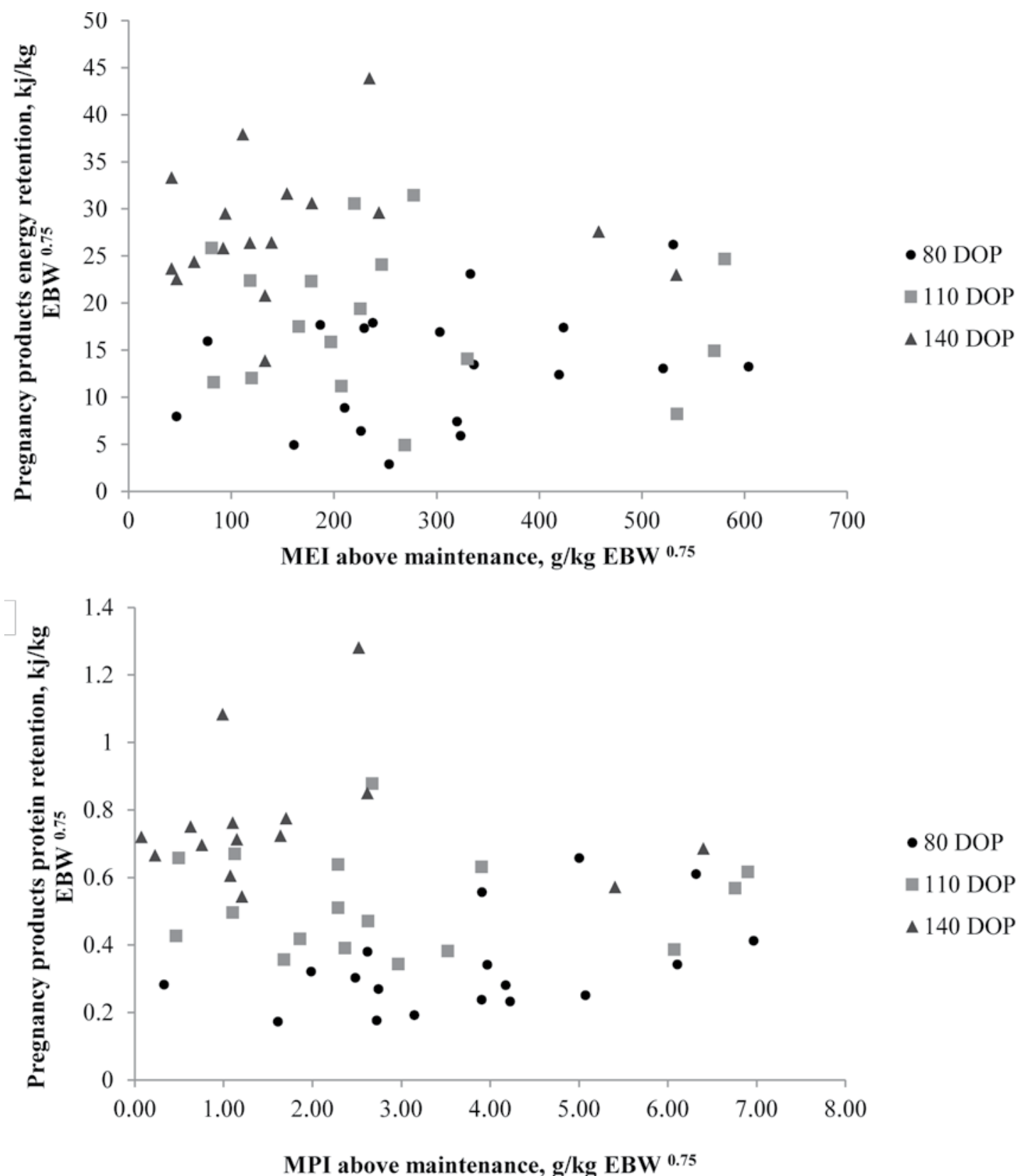

Figure 2. Metabolizable energy intake (MEI) and MP intake (MPI) above maintenance related to the energy and protein accretion on pregnancy products, respectively, from 80 to $140 \mathrm{~d}$ of pregnancy (DOP). EBW = empty body weight.

\section{Conclusion}

We partially reject our hypotheses because there was no evidence that pregnancy or DOP affects $\mathrm{NE}_{\mathrm{m}}$, $\mathrm{ME}_{\mathrm{m}}, \mathrm{NP}_{\mathrm{m}}$, and $\mathrm{MP}_{\mathrm{m}}$ or $\mathrm{k}_{\mathrm{mE}}$ and $\mathrm{k}_{\mathrm{mP}}$. The $\mathrm{NE}_{\mathrm{m}}$ and $\mathrm{ME}_{\mathrm{m}}$ were 197 and $315 \mathrm{~kJ} / \mathrm{kg} \mathrm{EBW}^{0.75}$, respectively, and $\mathrm{k}_{\mathrm{mE}}$ was 0.63 . The $\mathrm{NP}_{\mathrm{m}}$ and $\mathrm{MP}_{\mathrm{m}}$, both estimated using the comparative slaughter technique, were 1.28 $\pm 0.314 \mathrm{~g} / \mathrm{kg} \mathrm{EBW} \mathrm{E}^{0.75}$ and $3.22 \mathrm{~g} \mathrm{MP} / \mathrm{kg} \mathrm{EBW}^{0.75}$, respectively, and the $\mathrm{k}_{\mathrm{mP}}$ was 0.40 . However, $\mathrm{k}_{\mathrm{pE}}$ and $\mathrm{k}_{\mathrm{pP}}$ increased with pregnancy progress and were 0.058 and 0.12 , respectively, at 80 DOP; 0.10 and 0.21 , respectively, at $110 \mathrm{DOP}$; and 0.19 and 0.43 , respectively, at 140 DOP. Finally, these findings show potential for reducing the production cost of goats through the formulation of more precise formulation of diets.

\section{LITERATURE CITED}

Agricultural and Food Research Council (AFRC). 1998. The nutrition of goats. CAB Int., New York, NY.

Agricultural Research Council (ARC). 1980. The nutrient requirements of ruminant livestock. Commonwealth Agricultural Bureaux, Slough, UK.

Almeida, A. K., K. T. Resende, S. P. Silva, D. C. Soares, M. H. M. R. Fernandes, and I. A. M. A. Teixeira. 2015a. Protein requirements for growth in male and female Saanen goats. R. Bras. Zootec. 44:397-404. doi:10.1590/S1806-92902015001100004 
Almeida, A. K., K. T. Resende, N. St-Pierre, S. P. Silva, D. C. Soares, M. H. M. R. Fernandes, A. P. Souza, N. C. D. Silva, A. R. C. Lima, and I. A. M. A. Teixeira. 2015b. Energy requirements for growth in male and female Saanen goats. J. Anim. Sci. 93:3932-3940. doi:10.2527/jas.2014-8632

Association of Official Analytical Chemists (AOAC). 1990. Official methods of analysis. 15th ed. AOAC, Gaithersburg, MD.

Bauman, D. E., and W. B. Currie. 1980. Partitioning of nutrients during pregnancy and lactation: A review of mechanisms involving homeostasis and homeorhesis. J. Dairy Sci. 63:15141529. doi:10.3168/jds.S0022-0302(80)83111-0

Bell, A. W., and D. E. Bauman. 1997. Adaptations of glucose metabolism during pregnancy and lactation. J. Mammary Gland Biol. Neoplasia 2:265-278. doi:10.1023/A:1026336505343

Bell, A. W., and R. A. Ehrhardt. 2000. Regulation of macronutrient partitioning between maternal and conceptus tissues in the pregnant ruminant. In: P. Cronje and E. A. Boomker, editors, Ruminant physiology: Digestion, metabolism, growth, and reproduction. CABI Int., Wallingford, UK. p. 275-293. doi:10.1079/9780851994635.0275

Blaxter, K. L. 1967. The energy expenditures of ruminants. In: The energy metabolism of ruminants. Hutchinson, London, England. p. 110-112.

Blaxter, K. L., and J. L. Clapperton. 1965. Prediction of amount of methane produced by ruminants. Br. J. Nutr. 19:511-522. doi:10.1079/BJN19650046

Castagnino, D. S., C. J. Härter, A. R. Rivera, L. D. Lima, H. G. O. Silva, B. Biagioli, K. T. Resende, and I. A. M. A. Teixeira. 2015. Changes in maternal body composition and metabolism of dairy goats during pregnancy. Rev. Bras. Zootec. 44:92-102. doi:10.1590/S1806-92902015000300003

Commonwealth Scientific and Industrial Research Organisation (CSIRO). 1990. Feeding standards for Australian livestock. Ruminants. CSIRO Publications, East Melbourne, VIC, Australia.

Etheridge, R. D., G. M. Pesti, and E. H. Foster. 1998. A comparison of nitrogen values obtained utilizing the Kjeldahl nitrogen and Dumas combustion methodologies (Leco CNS 2000) on samples typical of an animal nutrition analytical laboratory. Anim. Feed Sci. Technol. 73:21-28. doi:10.1016/S03778401(98)00136-9

Fan, X., A. Felsovalyi, S. A. Sivo, and S. C. Keenan. 2002. SAS for Monte Carlo studies: A guide for quantitative researchers. SAS Inst. Inc., Cary, NC.

Fernandes, M. H. M. R., A. R. C. Lima, A. K. Almeida, T. Borghi, I. A. M. A. Teixeira, and K. T. Resende. 2016. Fasting heat production of Saanen and Anglo Nubian goats measured using open-circuit facemask respirometry. J. Anim. Physiol. Anim. Nutr. 101:15-21. doi:10.1111/jpn.12512

Ferreira, A. C. D., E. A. Yáñez, A. N. Medeiros, K. T. Resende, J. M. Pereira Filho, M. H. M. R. Fernandes, A. K. Almeida, and I. A. M. A. Teixeira. 2015. Protein and energy requirements of castrated male Saanen goats. Small Rumin. Res. 123:88-94. doi:10.1016/j.smallrumres.2014.10.017

Ferrell, C., L. Koong, and J. Nienaber. 1986. Effect of previous nutrition on body composition and maintenance energy costs of growing lambs. Br. J. Nutr. 56:595-605. doi:10.1079/ BJN19860140

Figueiredo, F. O., R. F. Leite, N. R. St-Pierre, K. T. Resende, A. K. Almeida, A. P. Souza, and I. A. M. A. Teixeira. 2016. Energy and protein requirements of weaned male and female Saanen goats. J. Anim. Physiol. Anim. Nutr. (In press.) doi:10.1111/ jpn.12539
Forbes, J. M., editor. 2007. Voluntary food intake and diet selection in farm animals. CAB Int., Wallingford, UK. doi:10.1079/9781845932794.0000

Freitas, V. J. F., G. Baril, and J. Saumandel. 1996. Induction and synchronization of estrus in goats: The relative efficiency of one versus two fluorogestone acetate-impregnated vaginal sponges. Theriogenology 46:1251-1256. doi:10.1016/S0093691X(96)00296-8

Graham, N. McC., W. Searle, and D. A. Griffiths. 1974. Basal metabolic rate in lambs and young sheep. Aust. J. Agric. Res. 25:957-971. doi:10.1071/AR9740957

Grummer, R. R. 1995. Impact of changes in organic nutrient metabolism on feeding the transition dairy cow. J. Dairy Sci. 73:2820-2833.

Gunter, S. A., M. B. Judkins, L. J. Krysl, J. T. Broesder, R. K. Barton, B. R. Rueda, D. M. Hallford, and D. W. Holcombe. 1990. Digesta kinetics, ruminal fermentation characteristics and serum metabolites of pregnant and lactating ewes fed chopped alfalfa hay. J. Anim. Sci. 68:3821-3831. doi:10.2527/1990.68113821x

Hafez, E. S. E., and B. Hafez, editors. 2000. Reproduction in farm animals. 7th ed. Lippincott Williams and Wilkins, Philadelphia, PA. doi:10.1002/9781119265306

Hanks, D. R., M. B. Judkins, B. A. McCracken, D. W. Holcombe, L. J. Krysl, and K. K. Park. 1993. Effects of pregnancy on digesta kinetics and ruminal fermentation in beef cows. J. Anim. Sci. 71:2809-2814.

Härter, C. J., J. L. Ellis, J. France, K. T. Resende, and I. A. M. A. Teixeira. 2016. Net energy and protein requirements for pregnancy differ between goats and sheep. J. Anim. Sci. 94:24602470. doi: $10.2527 /$ jas.2015-9673

Jarrige, R., editor. 1989. Ruminant nutrition. Recommended allowances and feed tables. INRA, Paris, France.

Labussière, E., J. van Milgen, C. F. M. de Lange, and J. Noblet. 2011. Maintenance energy requirements of growing pigs and calves are influenced by feeding level. J. Nutr. 141:1855-1861. doi:10.3945/jn.111.141291

Lindstrom, M. L., and D. M. Bates. 1990. Nonlinear mixed effects models for repeated measures data. Biometrics 46:673-687. doi: $10.2307 / 2532087$

Littell, R. C., G. A. Milliken, W. W. Stroup, R. D. Wolfinger, and O. Schabenberger. 2006. SAS system for mixed models. 2nd ed. SAS Inst. Inc., Cary, NC.

Lofgreen, G. P., and W. N. Garrett. 1968. A system for expressing net energyrequirements and feed values for growing and finishing beef cattle. J. Anim. Sci. 27:793-806. doi:10.2527/ jas1968.273793x

Luo, J., A. L. Goetsch, I. V. Nsahlai, T. Sahlu, C. L. Ferrel, F. N. Owens, M. L. Galyean, J. E. Moore, and Z. B. Johnson. 2004a. Metabolizable protein requirements for maintenance and gain of growing goats. Small Rumin. Res. 53:309-326. doi:10.1016/j. smallrumres.2004.04.003

Luo, J., A. L. Goetsch, T. Sahlu, I. V. Nsahlai, Z. B. Johnson, J. E. Moore, M. L. Galyean, F. N. Owens, and C. L. Ferrell. 2004b. Prediction of metabolizable energy requirements for maintenance and gain of preweaning, growing and mature goats. Small Rumin. Res. 53:231-252. doi:10.1016/j.smallrumres.2004.04.006

Mattison, D. R., E. Blann, and A. Malek. 1991. Physiological alterations during pregnancy: Impact on toxicokinetics. Fundam. Appl. Toxicol. 16:215-218. doi:10.1016/0272-0590(91)90103-B

McNeill, D. M., R. Slepetis, R. A. Erhardt, D. A. Smith, and A. W. Bell. 1997. Protein requirements of sheep in late pregnancy: Partioning between gravid uterus and maternal tissues. J. Anim. Sci. 75:809-816. doi:10.2527/1997.753809x 
NRC. 2001. Nutrient requirements of dairy cattle. 7th rev. ed. Natl. Acad. Press, Washington, DC.

NRC. 2007. Nutrient requirements of small ruminants. Sheep, goats, cervids and New World camelids. Natl. Acad. Press, Washington, DC.

Rattray, P. V., W. N. Garrett, N. E. East, and N. Hinman. 1973. The net energy requirements of ewe lambs for maintenance, gain and pregnancy and the net energy value of feedstuffs for lambs. J. Anim. Sci. 37:853-857. doi:10.2527/jas1973.373853x

Rattray, P. V., W. N. Garrett, N. E. East, and N. Hinman. 1974. Growth, development and composition of the ovine conceptus and mammary gland during pregnancy. J. Anim. Sci. 38:613626. doi:10.2527/jas1974.383613x

Reynolds, L. P., J. S. Caton, D. A. Redmer, A. T. Grazul-Bilska, K. A. Vonnahme, P. P. Borowicz, J. S. Luther, J. M. Wallace, G. Wu, and T. E. Spencer. 2006. Evidence for altered placental blood flow and vascularity in compromised pregnancies. J. Physiol. 572(1):51-58. doi:10.1113/jphysiol.2005.104430

Ritar, A. J., W. C. M. Maxwell, and S. Salamon. 1984. Ovulation and LH secretion in the goat after intravaginalprogestogen sponge-PMSG treatment. J. Reprod. Infertil. 72:559-563. doi:10.1530/jrf.0.0720559
Robertson, J. B., and P. J. Van Soest. 1981. The detergent system of analysis and its application to human foods. In: W. P. T. James and $\mathrm{O}$. Theander, editors, The analysis of dietary fiber in foods. Marcel Dekker, New York, NY. p. 123-158.

Rolim, G. S., M. B. P. Camargo, D. G. Lania, and J. F. L. Moraes. 2007. Classificação climática de köppen e de thornthwaite e sua aplicabilidade na determinação de zonas agroclimáticas para o estado de São Paulo. (In Portuguese.) Bragantia 66:711-720. doi:10.1590/S0006-87052007000400022

Salah, N., D. Sauvant, and H. Archimède. 2014. Nutritional requirements of sheep, goats and cattle in warm climates: A meta-analysis. Animal 8:1439-1447. doi:10.1017/S1751731114001153

U.S. Institute of Medicine. 1990. Committee on Nutritional Status During Pregnancy and Lactation. Nutrition during pregnancy, part I: Weight gain; part II: Nutrient supplements. Natl. Acad. Press, Washington, DC.

Voicu, I. G., H. Burlacu, R. D. Criste, and D. Voicu. 1993. Study on the energy and protein requirements in goats. Arch. Anim. Nutr. 44:47-61. 